\title{
The Risk to The Health of the Population Exposed to the Influence of the Road-Car Complex
}

\author{
Rachmaninoff Yuri ${ }^{1}$, Levanchuk Alexander ${ }^{2 *}$ and Koptenkova Olga ${ }^{3}$ \\ ${ }^{1}$ Research Institute of human ecology and environmental hygiene, Sysina of the Ministry of health of the Russian Federation, Russia \\ ${ }^{2}$ Northwestern state medical University, Mechnikov of Ministry of healthcare of the Russian Federation, Russia \\ ${ }^{3}$ St. Petersburg state University, St. Petersburg, University embankment, Russia
}

Received: 制: September 29, 2018; Published: 制: October 15, 2018

*Corresponding author: Levanchuk Alexander, Northwestern state medical University, Mechnikov of Ministry of healthcare of the Russian Federation, 195067, Saint-Petersburg, Russia

\begin{abstract}
Background: The growth of motorization of the population is accompanied by an increase in the number of environmental pollutants. In this study, the impact on public health risk indicators of not only gaseous but also dust components entering the environment during the operation of vehicles was studied.

Methods: A quantitative assessment of the impact of the process of operation of the road-car complex (DAC) of different intensity on air pollution. Then we determined the value of the indicator of risk to public health at different intensity of air pollution by products of operation of the DAC. The dependence of the risk to public health on the distance to roads with different traffic intensity was determined.

Results: The growth of motorization of the population has led to the formation of a high level of air pollution in megacities during the combustion of fuel, destruction of the road surface, parts of the braking system and tires of the car. Solid dust particles in atmospheric air samples are $70 \%$ represented by aluminosilicates, which have a fibrogenic effect, contain heavy metal compounds and substances with a pronounced carcinogenic effect (Benz-(a)-pyrene, dibenzo- (a, h)-anthracene, Benz-(B)-fluoranthene and chrysene). It is shown that non-carcinogenic risk in the area of DAC influence with the intensity of traffic flows 2500-3000 cars / hour, in the period up to the age of 30 years is estimated as" negligible", in 40 years as" moderate", at the age of 50 years as" high", for the age over 53 years as" very high "Critical systems are respiratory and cardiovascular. The dependence of the risk value on the distance to the road is established.
\end{abstract}

\section{Introduction}

Road transport has become the main source of air pollution in major cities. The negative impact on the health of the population of air pollutants of residential areas due to emissions of vehicles has not been fully studied, due to their multicomponent, as well as the extreme complexity of the organization of research in a metropolis. The only real possibility for obtaining quantitative characteristics of the potential threat is the use of methods for assessing and analyzing the risk to public health [1-8,9]. This study is aimed at assessing the level of air pollution (AB) and a comparative analysis of the risk to health of the population living in the zone of influence of chemical air pollutants at different distances from the DAC with different intensity of road transport.

\section{Methods}

Quantitative assessment of contamination of $\mathrm{AV}$ when operating the DAC of varying intensity. The following methods were used: chromatographic method for determination of organic compounds; atomic absorption method for determination of heavy metal compounds in the composition of solid dust particles; dust analyzer model 8520 for determination of PM10 and PM2.5 in the range of $0.001-100 \mathrm{mg} / \mathrm{m}^{3}$. Air sampling was carried out continuously for 8-12 hours. The study was conducted in the period 2009-2013 (796 air samples, 3077 samples). Assessment of health risk conducted in accordance with the guidance "Guidance on risk assessment for public health when exposed to chemical pollutants environment" (P 2.1.10.1920-04) [10] for the population residing on territories in the zone of influence DAK with the intensity of traffic flow 2500 cars / hour. As a control of the territory adopted in the territory in the zone of influence DAK with intensity of movement of transport streams 1000 cars / hour. The indicators of carcinogenic and noncarcinogenic risk were determined. Additionally, for risk assessment used guidelines 2.1.10.0062 - 12 "quantifying non-cancer risk from exposure to chemicals on the basis of evolutionary models" [11].

\section{Study Design}

Based on full-scale study determined the intensity of traffic flows in the selected study areas of the city. We considered the composition of vehicles, the main categories of vehicles (trucks, buses, cars), engine type. Sections of highways in residential areas 
are grouped considering the intensity of traffic flows in the daytime: up to 500 cars per hour ( 7 sections); 1500 - 2000 cars per hour (8 sections); 2500 - 3000 cars per hour (7 sections). In the areas of influence of DAC with different intensity of traffic flows conducted full-scale studies of atmospheric air accredited laboratory. The identified characteristics of the level of air pollution allowed to form a database to identify the connection in the system "DAC-air pollution-risk to public health". At the final stage, we determined the value of the indicator of risk to public health at different intensity of air pollution by the products of operation of the DAC. The dependence of the risk to public health on the distance to roads with different traffic intensity was established.

\section{Sensitivity Analysis}

Metrological characteristics were evaluated during the certification of the methods used [12-14].

\section{Results}

The results of field studies conducted in residential areas of the city, in areas along the roads with different intensity of traffic flows
(TP) allowed to establish the following. On the site with an intensity of 2500-3000 TP cars / hour revealed the most unfavorable situation. The maximum single concentration reached 3.3 maximum permissible concentration (MPC) for carbon monoxide, 8.2 MPC for nitrogen dioxide. In TP 1500-2000 cars / hour they reached 3.1 MPC for carbon monoxide and 4.5 MPC for nitrogen dioxide per hour. In the TP area less than 500 cars / hour of carbon monoxide-2.9 MPC, nitrogen dioxide-2.2 MPC. Contamination of $\mathrm{AB}$ along the roads with fine dust particles occurs because of primary dust formation - combustion of fuel components and abrasive processes of DAC, as well as secondary dust formation (resuspending dust particles). In the study of samples air of residential areas on the content of TSP at different distances from the roadway with traffic intensity of 2000-2500 watts./ hour at the edge of the road was determined $2.83 \pm 0.51 \mathrm{mg} / \mathrm{m} 3$; at a distance of $10 \mathrm{~m}-1.04 \pm 0.12 \mathrm{mg} / \mathrm{m} 3$; at a distance of $20 \mathrm{~m}-0.68 \pm 0.15 \mathrm{mg} / \mathrm{m} 3$; at a distance of $30 \mathrm{~m}-0.61 \pm$ $0.10 \mathrm{mg} / \mathrm{m}^{3}$; at a distance of $50 \mathrm{~m}-0.48 \pm 0.09 \mathrm{mg} / \mathrm{m} 3$; at a distance of $60 \mathrm{~m}-0.42 \pm 0.09 \mathrm{mg} / \mathrm{m} 3$. The content of solid dust particles of different dispersion in samples $\mathrm{AB}$ at up to $10 \mathrm{~m}$ from the roadway is presented in Table 1.

Table 1: content of solid dust particles in atmospheric air samples in residential areas with traffic flows of different intensity (mg / $\left.\mathrm{m}^{3}\right), \mathrm{M} \pm \mathrm{m}$. Differences are statistically significant $\mathrm{P}<0.05$.

\begin{tabular}{|c|c|c|c|c|}
\hline \multirow{2}{*}{ Dust Particles } & \multirow{2}{*}{ MPC, Мг/M $\mathbf{M}^{3}$} & \multicolumn{3}{|c|}{ Exceeding the Maximum Permissible Concentration (MPC) at Traffic Intensity (Cars/Hour) $M \pm M$} \\
\hline & & $\leq 500(n=112)$ & $1500-2000(n=128)$ & $2500-3000(n=112)$ \\
\hline TSP & 0,5 & $0,61 \pm 0,13$ & $2,1 \pm 0,54 * t=2,68$ & $2,86 \pm 0,63 * t=3,50$ \\
\hline PM10 & 0,30 & $0,39 \pm 0,09$ & $1,49 \pm 0,36^{*} t=2,98$ & $1,98 \pm 0,45^{*} \mathrm{t}=3,46$ \\
\hline PM2,5 & 0,16 & $0,15 \pm 0,04$ & $0,51 \pm 0,11^{*} \mathrm{t}=3,08$ & $0,91 \pm 0,16^{*} \mathrm{t}=4,61$ \\
\hline
\end{tabular}

According to the chemical analysis of TSP samples in AB on 70 $\%$ are aluminosilicates and are in the state of microscopic particles. It was found that the average concentrations of Zinc, Iron, Cobalt, Lead, Chromium, Nickel, Exceed hygienic standards with traffic intensity of more than 1500 cars/hour (Table 2). Differences between indicators of the content of all studied metals in samples of $\mathrm{AB}$ along the highway with intensity of TP to 500 cars/hour, 1500-2000 cars/hour and 2500-3000 cars/hour are statistically significant $(\mathrm{p}<0.05, \mathrm{f}=13$ and $\mathrm{f}=12$, respectively). Currently, there is an increase in environmental pollution by such supertoxic compounds as polycyclic aromatic hydrocarbons (PAHs). The main source of PAH in the road network is emissions from road transport. Chromatographic study of atmospheric air samples in the residential area at the border of the highway with the intensity of TP 2500-3000 cars/hour identified 86 organic compounds, 34 of which are cumulative and have not been previously accounted for. In the surface layer of the atmosphere clearly manifested dimethylnaphthalenes. Additionally, the following substances have been identified: Benz(a)anthracene, Benz(a)pyrene, Benz(e) pyrene, Benz (B) fluoranthene, Benz (k) fluoranthene, Benz (ghi) perylene, dibenz $(\mathrm{a}, \mathrm{h})$ anthracene, coronene, pyrene, chrysene. Of the identified substances, four (Benz (a) pyrene, dibenz (a, h) anthracene, Benz (b) fluoranthene and chrysene have a pronounced carcinogenic effect.

Table 2: content of metal compounds in atmospheric air samples along roads with different vehicle traffic intensity (mg / m3). Differences are statistically significant $\mathrm{P}<0.05$.

\begin{tabular}{|c|c|c|c|c|}
\hline \multirow{2}{*}{ Substance } & \multirow{2}{*}{ MPC, $\mathbf{M r} / \mathbf{M}^{3}$} & \multicolumn{3}{|c|}{ Exceeding the Maximum Permissible Concentration (MPC) at Traffic Intensity (Cars/Hour) $M \pm M$} \\
\hline & & $\leq 500(n=63)$ & $1500-2000(n=96)$ & $2500-3000(n=63)$ \\
\hline $\mathrm{Cu}$ & 0,002 & $0,16 \pm 0,04$ & $0,75 \pm 0,02^{*}$ & $0,92 \pm 0,05^{*}$ \\
\hline $\mathrm{Pb}$ & 0,0003 & $0,47 \pm 0,01$ & $1,29 \pm 0,24^{*}$ & $1,84 \pm 0,27^{*}$ \\
\hline $\mathrm{Cd}$ & 0,0003 & $<$ & $<$ & $0,02 \pm 0,003$ \\
\hline $\mathrm{Ni}$ & 0,001 & $0,01 \pm 0,002$ & $1,02 \pm 0,14^{*}$ & $1,6 \pm 0,31^{*}$ \\
\hline $\mathrm{Cr}$ & 0,0015 & $0,18 \pm 0,03$ & $1,10 \pm 0,09 *$ & $1,14 \pm 0,095^{*}$ \\
\hline Co & 0,0004 & $0,24 \pm 0,05$ & $1,50 \pm 0,34^{*}$ & $1,83 \pm 0,39 *$ \\
\hline $\mathrm{Zi}$ & 0,05 & $0,94 \pm 0,11$ & $3,6 \pm 0,86^{*}$ & $4,65 \pm 0,94^{*}$ \\
\hline $\mathrm{Fe}$ & 0,04 & $0,52 \pm 0,06$ & $3,5 \pm 0,47^{*}$ & $4,26 \pm 0,52^{*}$ \\
\hline
\end{tabular}




\section{Discussion}

It is established that the value of the indicators of carcinogenic risk in the zone of influence DAK with the intensity of the traffic flow 1000 cars/hour are mainly at the level of 10-4-10-5, typical for most major cities [15-17,18]. At the same time, the values of carcinogenic risk indicators in the zone with traffic intensity of 2500 cars/hour and above are at 10-2, which characterizes carcinogenic risk as "above acceptable". In international practice, this indicator corresponds to the quantitative criterion under which risk reduction measures should be implemented (Figure 1). The leading place among carcinogens is occupied by chromium and formaldehyde, followed by heavy metal compounds (Lead, Cobalt, Nickel and Cadmium). Heavy metal compounds and formaldehyde also contribute to the total non-carcinogenic risk index. Calculations have shown that the level of risk in the area with the intensity of TP
1000 cars/hour is estimated as "average". In the area with intensity TP 2500 cars/hour - as " extremely high." The main systems of non-carcinogenic risk are the respiratory and immune. In risk assessment using evolutionary models, it was found that the risk of health loss due to cardiovascular disease (CCC) due to chemical contamination of $\mathrm{AB}$ in areas with a TP intensity of less than 500 cars/hour is negligible and is less than $1.00 \mathrm{E}-04$ by age 73 . The magnitude of the risk of health loss due to the pathology of the respiratory system throughout life in DAC with an intensity of TP 2500-3000 cars/hour is 0.78 and almost 3 times higher than the risk of loss of health due to CCC pathology (0.26). The generalized risk before the age of 30 is negligible, at the age of 40 years as moderate, at the age of 50 years as high, for the age over 53 years as "very high". In addition, a reduction in life expectancy by 8.2 years (to 64.8 years, compared with the estimated life expectancy of 73 years) was revealed $[19,20]$.

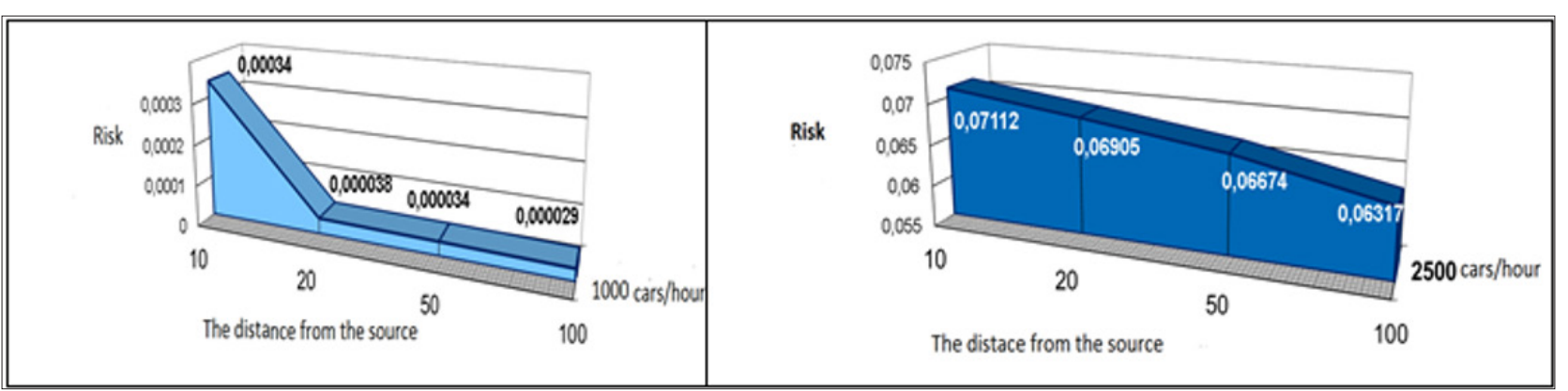

Figure 1: Carcinogenic risk in different parts of the residential area in the area of influence of the DAC with different intensity of traffic flows.

\section{Conclusion}

The results of the study of atmospheric air in influence of the DAC allowed to establish that the process of operation of cars leads to environmental pollution TSP which includes heavy metal compounds and polycyclic aromatic hydrocarbons. The intensity of pollution depends on the intensity of traffic flow on the road network. The population living in the area affected by roads with heavy traffic has a risk of loss of health due to the pathology of the respiratory, cardiovascular systems, as well as carcinogenic pathology because of the influence of chemical air pollutants. The life expectancy of the population living under the influence in DAK with the intensity of traffic 2500-3000 cars/hour, will be 64.8 years, i.e. 8.2 years less, compared with the exposure at a traffic intensity of less than 500 cars/hour.

\section{Acknowledgment}

This work was done in Northwestern state medical University them. I. I. Mechnikov of Ministry of healthcare of the Russian Federation.

\section{Acknowledgement}

This pooled analysis was funded by SSTP "New methods of medical care", section "Transplantation of cells, tissues and organs" (2016-2020), and by grant 000 "Synergy".

\section{References}

1. (1992) EPA (U.S. Environmental Protection Agency) Guidelines for Exposure Assessment. EPA 600Z-92/001 // Risk Assessment Forum. U.S. Environmental Protection Agency. Washington DC:178-233.

2. Rakhmanin Yu A, Novikov SM, Shashina TA (2007) Modern trends in risk assessment methodology. Gigiena i sanitariya 3: 3-8.

3. Kopytenkova OI, Levanchuk AV, Mingulova IR (2012) Gigienicheskaya harakteristika himicheskogo zagryazneniya okruzhayushchej sredy v processe ehkspluatacii transportno-dorozhnogo kompleksa/ Profilakticheskaya i klinicheskaya medicina. 3: 87-92.

4. Berico M, Luciani A, Formignani M (1997) Atmospheric aerosol in an urban area - measurements of TSP and PM 10 standards and pulmonary deposition assessments. Atmospheric Environment 31(21): 3659-3665.

5. XX Zhang, X Chen, ZF Wang, YH Guo, J Li, et al. (2017) Dust deposition and ambient PM 10 concentration in Northwest China: spatial and temporal variability. Atmospheric Chemistry and Physics 17(3): 1699-1711.

6. A Soriano, S Pallarés, AB Vicente, T Sanfeliu, MM Jordán (2011) Assessment of the main sources of PM 10 in an industrialized area situated in a Mediterranean Basin. Fresenius Environmental Bulletin 20(9): 23792390.

7. V Bernardoni, R Vecchi, G Valli, A Piazzalunga, P Fermo (2011) PM 10 Source apportionment in Milan (Italy) using time-resolved data. Science of the Total Environment 409(22): 4788-4795.

8. JM Lim, JH Moon, YS Chung, JH Lee, KH Kim (2010) Airborne PM 10 and metals from multifarious sources in an industrial complex area. Atmospheric Research 96(1): 53-64. 
9. AB Strelyaeva, NS Barikaeva, EA Kalyuzhina, DA Nikolenko (2014) Analiz istochnikov zagryazneniya atmosfernogo vozduha melkodispersnoj pyl'yu [EHlektronnyj resurs]. Seriya: Politematicheskaya 3(34).

10. Metodicheskie rekomendatsii (2012) Quantitative assessment of non-carcinogenic risk when exposed to chemical substances on the basis of evolutionary models. Federal'nyy tsentr gigieny i epidemiologii Rospotrebnadzora. Moscow 36: 62-12.

11. Metodicheskie rekomendatsii (2011) Assessment of human health risk from exposure to transport noise. Federal'nyy tsentr gigieny i epidemiologii Rospotrebnadzora. Moscow 40: 59-12. (US. Environmental Protection Agency). 1992. Guidelines for Exposure Assessment. EPA 600Z92/001. Risk Assessment Forum. U.S. Environmental Protection Agency. Washington, DC pp. 178-233.

12. (2002) GOST R ISO 5725-2002 Tochnost' (pravil'nost' i precizionnost') metodov i rezul'tatov izmerenij 6 chastyah. IPK Izdatel'stvo standartov 2002.

13. MI 2336-2002 Pokazateli tochnosti, pravil'nosti, precizionnosti metodik kolichestvennogo himicheskogo analiza. Metody ocenki.

14. (2002) EUROCHEM/CITAC Guide Quantifying Uncertainty in Analytical Measu-rements, (2nd Edn.)., 2000. Imeetsya russkij perevod: Rukovodstvo EVRAHIM/SITAK “ «Kolichestvennoe opisanie neopredelennosti v analiticheskih izmereniyah», vtoroe izdanie. Per. s angl. RL Kadisa, GR Nezhihovskogo, VB Simina pod red. LA Konopel'ko. Sankt Peterburg, 2002 g. 141 s.

ISSN: 2574-1241

DOI: 10.26717/BJSTR.2018.10.001885

Levanchuk Alexander. Biomed J Sci \& Tech Res

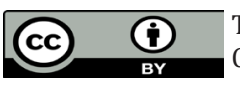

This work is licensed under Creative Commons Attribution 4.0 License

Submission Link: https://biomedres.us/submit-manuscript.php
15. G Polichetti, S Cocco, A Spinali, V Trimarco, A Nunziata (2009) Effects of particulate matter (PM 10, PM 2.5 and PM 1) on the cardiovascular system. Toxicology 261(1-2): 1-8.

16. N Künzli, R Kaiser, S Medina, M Studnicka, O Chanel, et al. (2000) Public-health impact of outdoor and traffic-related air pollution: a European assessment. The Lancet 356(9232): 795-801.

17. W Wang, T Yu, P Ciren, P Jiang (2015) Assessment of human health impact from PM 10 exposure in China based on satellite observations. Journal of Applied Remote Sensing (9)1: 15100.

18. IV Maj, SYU Zagorodnov, AA Maks, MYU Zagorodnov (2012) Ocenka potencial'nogo zagryazneniya atmosfernogo vozduha melkodispersnymi chasticami v zone raspolozheniya mashinostroitel'nogo predpriyatiya. Vestnik Permskogo nacional'nogo issledovatel'skogo politekhnicheskogo universiteta. Urbanistika (2): 109-118.

19. AB Strelyaeva, LM Lavrenteva, VV Lupinogin, IA Gvozdkov (2017) Issledovaniya zapylennosti v zhiloj zone, raspolozhennoj vblizi promyshlennyh predpriyatij chasticami RM 10 i RM 2.5. Inzhenernyj vestnik Dona 45(2): 154-156.

20. Prosviryakova IA (2015) Metodologicheskie podhody k gigienicheskoj ocenke soderzhaniya melkodispersnyh tverdyh chastic $\mathrm{v}$ atmosfernom vozduhe. Zdorov'e i okruzhayushchaya sreda: sbornik nauchnyh trudov. pod red. S.I. Sychika. Minsk: RNMB 1(25): 85-87.

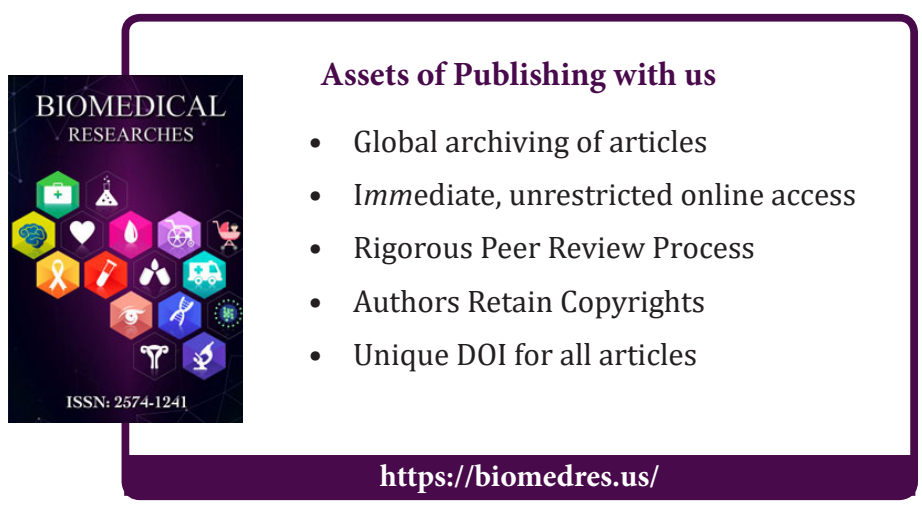

